\title{
PENDAMPINGAN INTRODUKSI BAYAM BRAZIL SEBAGAI SAYUR PEKARANGAN DI KOTA BANJARBARU
}

\section{ASSISTANCE IN THE INTRODUCTION OF BRAZILIAN SPINACH AS VEGETABLE BACKYARD IN BANJARBARU TOWN}

\author{
Hikma Ellya $^{1)^{*}}$, Nurlaila ${ }^{2)}$, Nukhak Nufita Sari ${ }^{3)}$, Rila Rahma Apriani ${ }^{4)}$, Ronny \\ Mulyawan", $^{5}$, Febriani Purba ${ }^{6}$, Saida Fithria ${ }^{7)}$ \\ ${ }^{1)}$ Fakultas Pertanian, Universitas Lambung Mangkurat. email: hikma.ellya@ulm.ac.id \\ ${ }^{2)}$ Fakultas Pertanian, Universitas Lambung Mangkurat. email: nur.laila@ulm.ac.id \\ ${ }^{3)}$ Fakultas Pertanian, Universitas Lambung Mangkurat. email: nukhak.sari@ulm.ac.id \\ ${ }^{4)}$ Fakultas Pertanian, Universitas Lambung Mangkurat. email: rila.rahma@ulm.ac.id \\ ${ }^{5)}$ Fakultas Pertanian, Universitas Lambung Mangkurat. email: ronny.mulyawan@ulm.ac.id \\ ${ }^{6)}$ Fakultas Pertanian, Universitas Lambung Mangkurat. email: febriani.purba@ulm.ac.id \\ ${ }^{7)}$ Dinas Ketahanan Pangan, Pertanian, dan Perikanan Kota Banjarbaru. \\ email: saida.fithria@gmail.com
}

\begin{abstract}
ABSTRAK
Banjarbaru merupakan kota pemukiman yang sebagian besar penduduknya tinggal di lahan sempit. Diversifikasi tanaman pekarangan perlu dilakukan di Kota Banjarbaru. Salah satu tanaman pekarangan yang mulai dibudidayakan masyarakat perkotaan pada saat ini dikenal dengan sebutan bayam Brazil (Alternanthera sissoo). Tanaman ini mulai diimpor dan diperkenalkan ke beberapa negara Asia Tenggara, seperti Malaysia dan Indonesia. Kegiatan pengabdian ini bertujuan untuk memberikan pendampingan introduksi tanaman Bayam Brazil sebagai tanaman pekarangan di Kota Banjarbaru. Metode kegiatan yang digunakan dalam pengabdian kepada masyarakat ini adalah metode penyuluhan dan pendampingan. Kegiatan penyuluhan dilaksanakan di Aula Gawi Sabarataan Balai Kota Pemerintah Kota Banjarbaru selama satu hari. Peserta kegiatan berjumlah 59 orang yang terdiri dari Ketua Kelompok Wanita Tani, Ketua Dasa Wisma, dan Tim Penggerak PKK Kota Banjarbaru. Pendampingan penanaman bayam Brazil dilakukan di beberapa kelompok wanita tani. Masyarakat Kota Banjarbaru sangat antusias untuk menanam tanaman bayam Brazil di pekarangan. Hal ini karena tanaman bayam Brazil dapat dikonsumsi, mudah diperbanyak, mudah dibudidayakan, dan memiliki bentuk yang estetik.
\end{abstract}

Kata kunci: Bayam Brazil, Lahan Pekarangan,Urban Farming

\section{ABSTRACT}

Banjarbaru is a residential city that mostly lives in narrow land. Diversification of yard plants needs to be done in Banjarbaru. One of the yard plants that began to be cultivated by urban communities today is known as Brazilian spinach (Alternanthera sissoo). This plant began to be imported and introduced to several Southeast Asian countries, such as Malaysia and Indonesia. This community service activity aims to provide assistance in the introduction of Brazilian spinach plants as vegetable backyard in Banjarbaru Town. The method of activity used in community service is the method of counseling and assistance. Counseling activities were held at Gawi Sabarataan Hall of Banjarbaru for one day. The participants of the activity numbered 59 people consisting of the Chairmans of the Farmer Women Groups, the Chairmans of Dasa Wisma, and the PKK (Family Welfare Development) Mobilization Team of Banjarbaru City. Assistance in planting Brazilian spinach was carried out in Farmer Women Groups. Banjarbaru people are very enthusiastic to grow Brazilian spinach plants in the yard. This is because Brazil spinach plants can be consumed, easily reproduced, easy to cultivate, and have an aesthetic shape.

Keywords: Brazilian Spinach, Backyard, Urban Farming 
PENDAHULUAN

Introduksi tanaman merupakan bagian penting dalam perluasan pertanian untuk memperluas pengetahuan tentang manfaat tanaman ke masyarakat luas di seluruh dunia. Penyebaran biji kopi dan kentang ke seluruh dunia merupakan contoh sukses introduksi tanaman.

Pekarangan merupakan lahan di sekitar tempat tinggal yang dapat dimanfaatkan untuk budidaya tanaman. Komoditas yang ditanam di pekarangan biasanya dapat berupa buah, sayuran, tanaman obat, dan tanaman hias [1]. Pekarangan semakin dimanfaatkan oleh masyarakat Indonesia seiring dengan adanya wabah Covid-19 pada sekitar awal tahun 2020. Peraturan untuk mengurangi interaksi sosial secara langsung menjadikan bertani di lahan pekarangan sebagai salah satu solusi untuk pemenuhan pangan keluarga di masa pandemi [2].

Ketersediaan lahan menentukan komoditas tanaman yang cocok dibudidayakan. Semakin luas lahan pekarangan, semakin beragam tanaman yang dapat ditanam pada lahan tersebut. Sebaliknya, semakin sempit lahan maka semakin sedikit pilihan jenis dan jumlah tanaman yang dapat dikelola. Penentuan komoditas tanaman pada lahan pekarangan khususnya di daerah perkotaan sangat penting. Komoditas yang ditanam biasanya selain untuk memenuhi pangan dan gizi keluarga, juga memenuhi nilai estetika agar terlihat indah ketika ditanam di sekitar tempat tinggal $[3,4]$.
Penduduk kota Banjarbaru sebagian besar memiliki pekerjaan utama sebagai pegawai atau karyawan. Bertanam di lahan pekarangan sering dilakukan oleh masyarakat di sela pekerjaan utama. Berdasarkan tren masyarakat tersebut, Dinas Ketahanan Pangan, Pertanian, dan Perikanan Kota Banjarbaru berinisiatif untuk membuat program diversifikasi tanaman pekarangan. Persuasi kepada masyarakat akan semakin kuat dengan melibatkan pihak akademisi sebagai sarana berbagi teori tentang jenis tanaman pekarangan.

Jenis tanaman pekarangan yang mulai dibudidayakan masyarakat perkotaan pada saat ini dikenal dengan sebutan bayam brazil (Toensmeier, 2007). Tanaman ini mulai diimpor dan diperkenalkan ke beberapa negara Asia Tenggara, seperti Malaysia dan Indonesia tepatnya. Permintaan sayuran jenis ini dapat ditemukan di media sosial, di Instagram misalnya dan di berbagai $e$ commerce Indonesia seperti Tokopedia, Bukalapak, Shopee dan lainnya. Permintaan yang tinggi terhadap bayam brazil dari para pembeli yang kebanyakan pecinta taman rumah.

Tujuan dari kegiatan pengabdian kepada masyarakat di Aula Gawi Sabarataan Balai Kota Pemerintah Kota Banjarbaru adalah untuk memberikan pendampingan introduksi tanaman Bayam Brazil untuk diversifikasi tanaman pekarangan di Kota Banjarbaru.

\section{METODE PELAKSANAAN KEGIATAN}

Sasaran kegiatan ini adalah masyarakat kota Banjarbaru khususnya kaum perempuan 
sebagai penggerak pangan keluarga.

Kegiatan ini sejalan dengan program Dinas

Ketahanan Pangan, Pertanian, dan Perikanan

Kota Banjarbaru yang bertujuan untuk diversifikasi pangan Kota Banjarbaru.

Kegiatan pendampingan bayam Brazil

dilakukan secara berkesinambungan selama sepuluh bulan.

Kegiatan awal berupa penyerahan bibit bayam Brazil ke beberapa Kelompok Tani bersama dengan para penyuluh pertanian dari Dinas Ketahanan Pangan, Pertanian, dan Perikanan Kota Banjarbaru pada tanggal 30 Juli 2020. Hal ini dilakukan dalam rangka melihat antusiasme masyarakat untuk bertanam bayam Brazil.

Kegiatan selanjutnya berupa penyuluhan. Penyuluhan dan diskusi dilaksanakan pada tanggal 3 September 2020 di Aula Gawi Sabarataan Balai Kota Pemerintah Kota Banjarbaru Provinsi Kalimantan Selatan. Materi pada penyuluhan berupa introduksi tanaman bayam Brazil, alasan budidaya tanaman, cara budidaya tanaman, dan potensi pengolahan hasil dengan bahan baku daun bayam Brazil.

Kegiatan pendampingan dilakukan secara periodik untuk mendampingi masyarakat dalam pengembangan budidaya bayam Brazil.

\section{HASIL DAN PEMBAHASAN}

Kota Banjarbaru merupakan salah satu Kotamadya di Provinsi Kalimantan Selatan. Kota Banjarbaru memiliki lima kecamatan yaitu, Kecamatan Liang Anggang, Kecamatan Landasan Ulin, Kecamatan
Banjarbaru Utara, Kecamatan Banjarbaru Selatan, dan Kecamatan Cempaka. Wilayah. Kota Banjarbaru memiliki luas wilayah $371,38 \mathrm{~km}^{2}$ dan jumlah penduduk 262.719 orang [5]. Kepadatan penduduk mencapai $707 \mathrm{jiwa} / \mathrm{km}^{2}$, hal ini mengakibatkan sempitnya lahan untuk pemenuhan pangan. Pemanfaatan tanaman pekarangan sebagai sumber pangan menjadi solusi di lahan sempit.

Penentuan komoditas di lahan sempit biasanya juga untuk menambah nilai estetik pekarangan, selain untuk pemenuhan pangan. Salah satu tanaman yang dapat dibudidayakan adalah bayam Brazil. Dinas Ketahanan Pangan, Pertanian, dan Perikanan Kota Banjarbaru memiliki program untuk mengembangkan bayam Brazil untuk diversifikasi tanaman pekarangan dengan melibatkan dosen dari Fakultas Pertanian Universitas Lambung Mangkurat. Program ini terdiri dari beberapa kegiatan dari penyerahan bibit sampai dengan pendampingan dalam pengembangan budidaya tanaman.

Kegiatan penyerahan bibit bayam Brazil merupakan kegiatan awal yang dilakukan bersama dengan penyuluh pertanian Pemerintah Kota Banjarbaru (Gambar 1). Kegiatan ini merupakan pengenalan awal masyarakat terhadap bayam Brazil. Transfer informasi secara sederhana tentang bayam Brazil juga dilakukan pada saat pembagian bibit tersebut. Masyarakat terlihat antusias saat dibagikan bibit tersebut. Mereka banyak tertarik melihat bentuk daun bayam Brazil 
yang berbentuk hati. Hal ini menjadi daya tarik lain dari tanaman bayam Brazil selain sebagai tanaman yang dapat dikonsumsi.

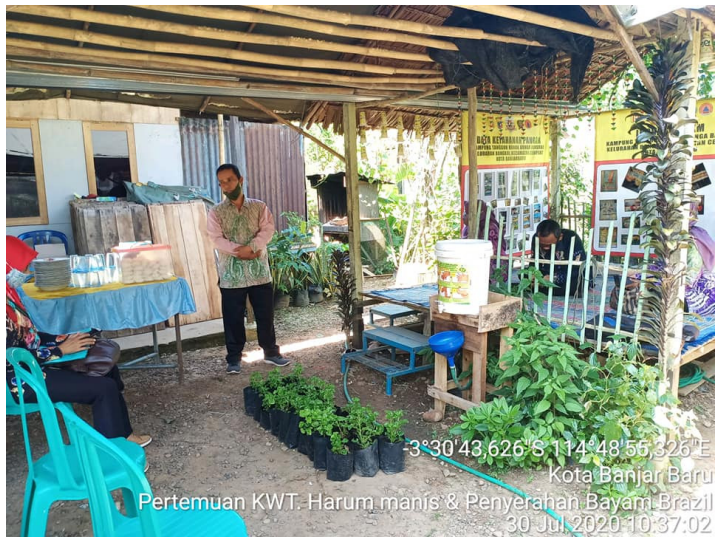

Gambar 1. Kegiatan penyerahan bibit bayam Brazil

Penyuluhan dan diskusi dilaksanakan pada tanggal 3 September 2020 di Aula Gawi Sabarataan Balai Kota Pemerintah Kota Banjarbaru Provinsi Kalimantan Selatan (Gambar 2). Materi pada penyuluhan berupa introduksi tanaman bayam Brazil, budidaya tanaman, dan potensi pengolahan hasil dengan bahan baku daun bayam Brazil. Peserta kegiatan berjumlah 59 orang yang terdiri dari Ketua Kelompok Wanita Tani, Ketua Dasa Wisma, dan Tim Penggerak PKK Kota Banjarbaru. Antusias peserta terlihat saat sesi tanya jawab. Peserta tertarik untuk mengembangkan bayam Brazil di pekarangan mereka masing-masing. Beberapa peserta juga tertarik untuk mencoba inovasi dalam pengolahan bayam Brazil. Penyuluhan dan diskusi ditutup dengan penyerahan secara simbolis bibit bayam Brazil (Gambar 3).

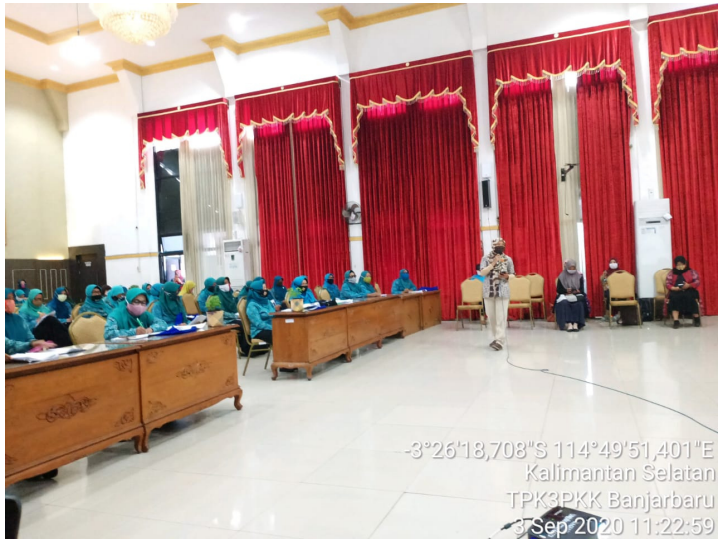

Gambar 2. Penyuluhan dan diskusi tentang bayam Brazil

Materi introduksi tanaman bayam Brazil terdiri dari penyampaian asal usul tanaman yang berasal dari Negara Brazil. Kesamaan letak lintang negara Indonesia dengan negara Brazil, menjadi alasan potensial tanaman tersebut dapat diintroduksi. Kesamaan letak lintang tersebut mengakibatkan kesamaan iklim pada umumnya. Iklim merupakan kebutuhan dasar bagi perkembangan tanaman. Tanaman akan lebih mudah beradaptasi pada iklim yang mirip dengan daerah asalnya.

Materi tentang budidaya tanaman terdiri dari penyampaian alasan budidaya bayam Brazil di pekarangan. Bayam Brazil dapat menjadi tanaman pekarangan karena mudah dalam perbanyakan tanaman dan berdaptasi di lingkungan tropis. Alasan lainnya adalah bayam Brazil merupakan tanaman tahunan, sehingga dapat tumbuh dalam waktu yang lama di sekitar pekarangan. Bayam Brazil juga memiliki nilai estetika dari bentuk daunnya yang berbentuk hati. Alasan yang paling utama adalah bayam Brazil merupakan edible plant atau tanaman yang dapat dikonsumsi. Sehinga dapat menjadi 
sumber pangan bagi keluarga.

Materi potensi pengolahan hasil dari bayam Brazil terdiri dari penyampaian beraneka macam olahan dengan bahan baku bayam Brazil. Bayam Brazil dapat diolah menjadi smoothies, salad, keripik, pewarna makanan, sayur bening, dan campuran olahan sayur lainnya.

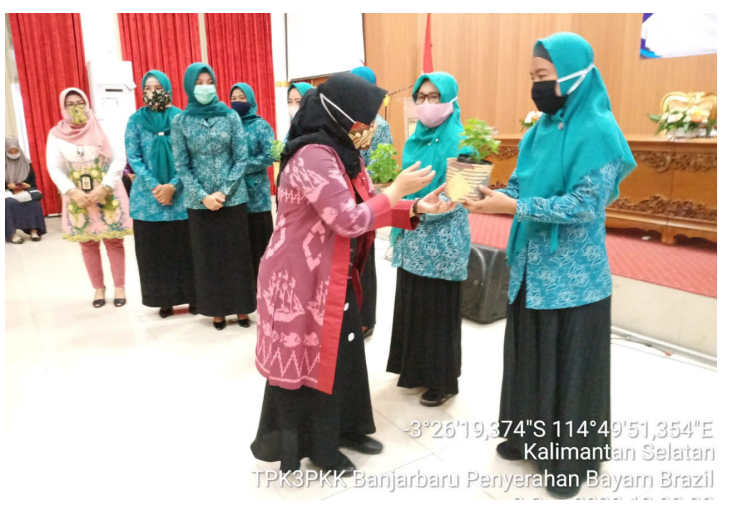

Gambar 3. Penyerahan simbolis bibit bayam Brazil

Kegiatan pendampingan dilakukan dengan mengunjungi beberapa kelompok tani wanita yang mengembangkan budidaya bayam Brazil (Gambar 4). Bayam Brazil kebanyakan ditanam di sekitar pekarangan dengan polybag, beberapa juga dengan system vertikultur. Beberapa kelompok tani juga mengembangkan budidaya bayam Brazil pada system hidroponik (Gambar 5). Lokasi tanaman bayam brazil bahkan menjadi lokal Hatinya PKK.

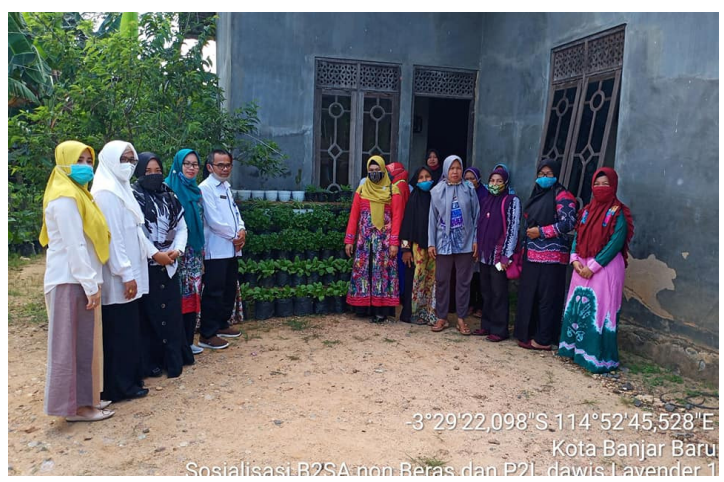

Gambar 4. Pendampingan pengembangan bayam Brazil

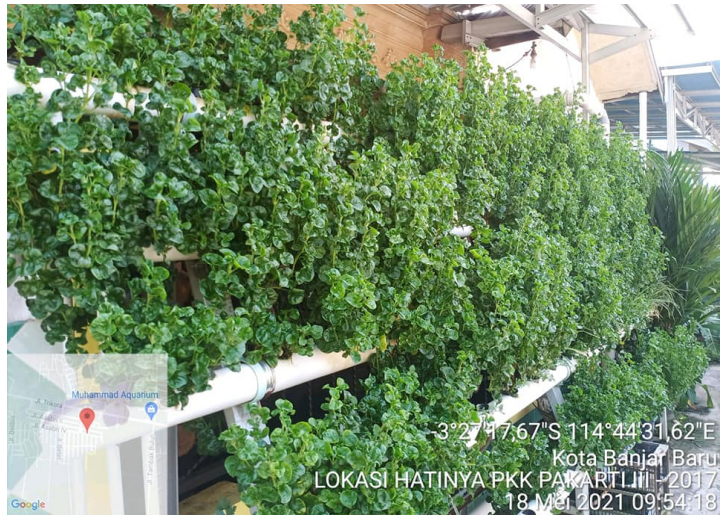

Gambar 5. Budidaya bayam Brazil pada system hidroponik

\section{KESIMPULAN}

Penduduk Kota Banjarbaru rata-rata memiliki lahan yang sempit untuk pemenuhan pangan. Bayam Brazil merupakan tanaman yang berpotensi dibudidayakan di pekarangan. Pendampingan introduksi bayam Brazil di kota banjarbaru dilaksanakan dengan metode penyuluhan dan pendampingan. Kegiatan penyuluhan dilaksanakan di Aula Gawi Sabarataan Balai Kota Pemerintah Kota Banjarbaru selama satu hari. Peserta kegiatan berjumlah 59 orang yang terdiri dari Ketua Kelompok Wanita Tani, Ketua Dasa Wisma, dan Tim Penggerak PKK Kota Banjarbaru. Pendampingan penanaman bayam Brazil dilakukan di beberapa kelompok wanita tani. Masyarakat Kota Banjarbaru sangat antusias untuk menanam tanaman bayam Brazil di pekarangan. Hal ini karena tanaman bayam Brazil dapat dikonsumsi, mudah diperbanyak, mudah dibudidayakan, dan memiliki bentuk yang estetik. 


\section{SARAN}

Pemenuhan pangan dan gizi keluarga dapat dimulai dari sekitar tempat tinggal. Pemanfaatan pekarangan adalah salah satu bentuknya. Oleh karena itu, perlu dipilih komoditas tanaman yang dapat dikonsumsi, mudah diperbanyak, mudah dibudidayakan, dan memiliki bentuk yang estetik.

\section{UCAPAN TERIMAKASIH}

Kami mengucapkan terima kasih kepada kelompok tani, dasa wisma, dan penggerak PKK Kota Banjarbaru yang telah berpartisipasi dalam kegiatan pengabdian kepada masyarakat ini. Kami juga mengucapkan terima kasih kepada Dinas Ketahanan Pangan, Pertanian, dan Perikanan Kota Banjarbaru yang telah berkenan dalam kerjasama kegiatan pengabdian ini. Kami juga mengucapkan terima kasih kepada Dekan Fakultas Pertanian dan ketua
Lembaga Penelitian dan Pengabdian kepada

Masyarakat Universitas Lambung Mangkurat yang telah memberi kesempatan untuk melakukan kegiatan pengabdian ini.

\section{REFERENSI}

[1] Siregar, N. N. And S. Wahyuni. 2018. Optimalisasi pemanfaatan lahan pekarangan sebagai sumber pangan. Amaliah : Jurnal Pengabdian Kepada Masyarakat 2 (1) : 146 - 149.

[2] Thesiwati, A.S. 2020. Pemanfaatan Lahan Pekarangan Sebagai Pangan Lestari di Masa Covid-19. Jurnal Pengabdian kepada Masyarakat Dewantara 3(2):25-30.

[3] Toensmeier, E. 2007. Perennial Vegetables. Chelsea Green Publishing. Vermont.

[4] Tregenza, R. 2016. Gardening for food and community. Landscape Review 16(2):86-93.

[5] BPS Kota Banjarbaru. 2020. Kota Banjarbaru dalam Angka. BPS. Banjarbaru 